\title{
Over One Hundred Million Simulations Delivered: A Case Study of the PhET Interactive Simulations
}

\author{
Raina Khatri*, Charles Henderson*, Renee Cole $†$ and Jeffrey Froyd ${ }^{\mathbb{I}}$ \\ *Department of Physics and Mallinson Institute for Science Education, Western Michigan University, \\ Kalamazoo, MI 49008, USA \\ + Department of Chemistry, University of Iowa, Iowa City, IA 52242, USA \\ "T Texas A\&M University, College Station, TX 77843, USA
}

\begin{abstract}
The PhET Interactive Simulations are well-known resources that originated in physics and are now used in multiple science disciplines. Many new educational innovations are developed but do not find a large audience-PhET, however, has been successful in becoming widely-used. This is the first of several planned case studies of widely-used educational innovations to characterize the strategies used by principle investigators (PIs) to promote widespread use of their innovation. We collected multiple sources of data, including interviews with the original developers, relevant publications, and documents released by the $\mathrm{PhET}$ team over the years. We analyzed the interview data and documents using a predetermined lens and constructed a narrative of key events and strategies. We found the PhET team refined and solidified the simulations after a period of pilot testing, and additional funding prompted new phases of propagation. With these results we refined our framework of successful propagation. The results of this work may help future PIs design a propagation plan for their innovation.
\end{abstract}

Keywords: Dissemination, Higher Education, Educational Change PACS: 01.40.Fk

\section{INTRODUCTION}

While there are many new innovations in physics teaching, few are widely used by physics faculty. One possible exception is the PhET Interactive Simulations, free downloadable simulations developed at the University of Colorado that represent physical systems and allow users to explore many concepts in physics and other disciplines. PhET simulations are widely used as a flexible teaching tool in K-12 and college settings across the world.

This paper presents preliminary results of the first case study of a planned multiple-case study. We wish to develop a framework for successful propagation using information from these studies. The primary goal of this case study is to understand how the PhET simulations became so widely used. Educational researchers tend to use traditional channels to share their work with others, such as publishing in journals and presenting at conferences [1]. However, these mass-market methods do not lead to adoption or adaptation of educational innovations. Change literature [2] suggests that change requires more guidance and interaction with a new idea before it is adopted than mass-market methods allow. This study responds by characterizing successful propagation practices through a multiple-case design [3]. This project will add to the understanding of how educational innovations spread from the developers to new adopters at other sites.

The main research question behind the multiplecase study is: What are the propagation practices that lead to the widespread use of an educational innovation?

The specific research questions for this case are:

1) How did the PhET Interactive Simulations begin?

2) What were the early viewpoints of the developers regarding the propagation of PhET, and how did this change over time?

3) What specific strategies did the developers use to propagate $\mathrm{PhET}$ ?

4) How did funding play a role in the propagation of $\mathrm{PhET}$ ?

\section{METHODS}

This study uses case study methodology [3]. Case study is ideal for studying contemporary events over which the researcher has no experimental control, and the research questions seek explanatory answers. The overall study follows a multiple-case design, in which several units of analysis (in this study, educational innovations) are compared in a final analysis stage. We used purposeful sampling of cases based upon a survey we conducted in fall 2012. This was an open-ended 


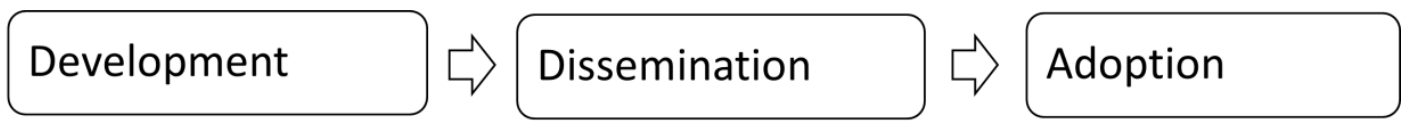

\section{Consider Assertions about Propagation}

FIGURE 1. Theoretical framework of factors leading to widespread adoption.

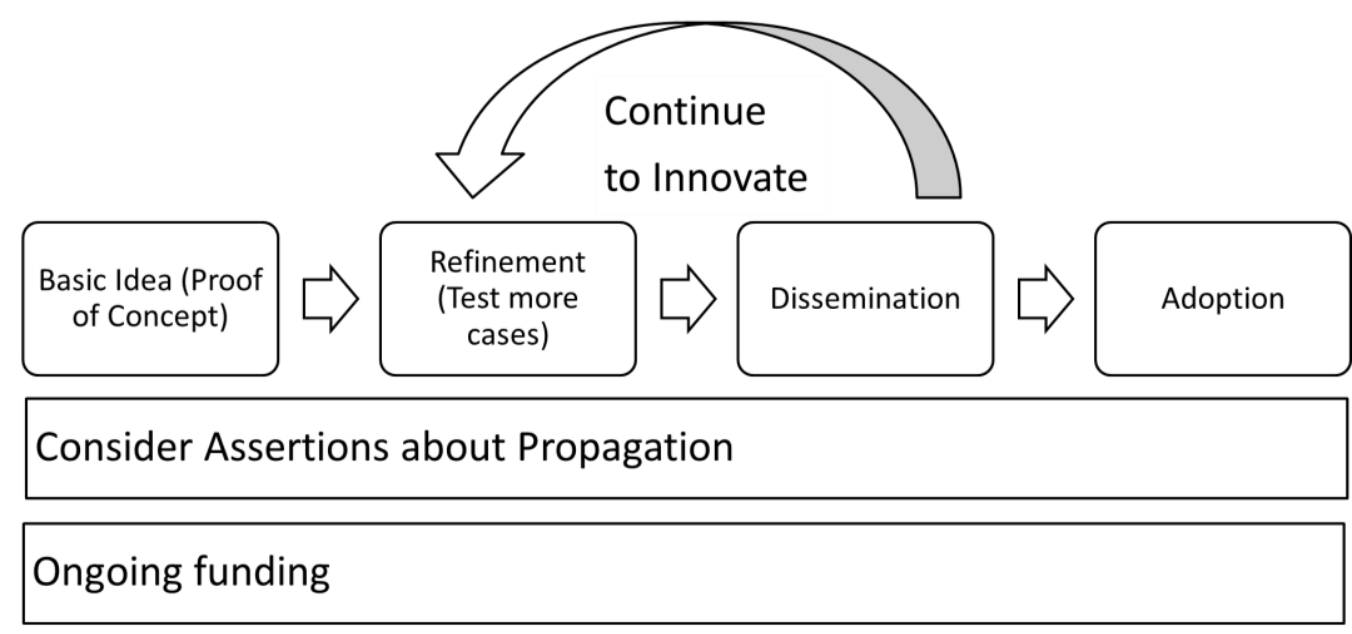

FIGURE 2. Working framework based on original framework, altered to include findings from the PhET study.

questionnaire emailed to experts in science and engineering education in which we asked what they believed to be widely-used educational innovations in undergraduate education. This list of innovations was compared with the literature and member checked. We developed several categories of innovation types, and chose innovations for case studies that represented a diversity of innovation types and disciplines. The PhET simulations represent a type of innovation which is flexible and easy to integrate into lecture or lab settings.

The data collected includes interviews with the initial PhET developing team, grant proposals over several years of PhET, publications on the process of developing simulations, press releases by news sources, newsletters, videos, and other documents released by the PhET team over the years. Interviews were conducted over the phone and recorded, then transcribed verbatim. The interviews were semistructured, using a script but allowing for follow-up questions. Multiple sources of data are key in conducting valid case studies; this allows the researcher to triangulate findings.

The analysis was an iterative process using explanation-building as a main analytic strategy. Explanation-building is another form of patternmatching, in which the researcher begins with a theoretical framework or statement and compares findings from the case to theory. In the additional case studies, conclusions from this study will be continually revised with new information from those cases.

The theoretical framework for the overall study is guided by change literature and theory developed by the authors [4][5], given in Figure 1. In the framework, propagation of the innovation takes place alongside the initial development. Propagation efforts should consider five assertions [4]: the barriers presented by the education system, that the type of innovation will dictate the types of strategies used, that multiple exposures to the new idea may be necessary, the beliefs of the target audience regarding the innovation may need to be addressed, and that change is a process, not an event. These development and dissemination phases then lead to adoption. This framework, along with literature on successful innovations [6] provides a lens through which to pull salient points from the data.

\section{RESULTS}

\section{1) How did the PhET simulations begin?}

The PhET website began in 2002, founded by Nobel Prize winner Carl Wieman. The idea for simulations began first with a predecessor to PhET called Physics 2000. Wieman was involved with the site as a science advisor, which led to using 
simulations as an illustrative tool while giving talks on Bose-Einstein condensate. Wieman found that the simulations were a great instructional tool that can be used for any age group, and he found that months after his talk, people would only remember the simulation.

"...he would hear from people six months to a year later, and all they remembered from his talk was the simulations, and they remembered the physics correctly from the simulations. Then he realized this is the thing. This is huge. This is what we need in the classroom." - PhET Team Member

Wieman used money from his Nobel Prize, his NSF Distinguished Teaching award, and money from the Kavli Foundation to start the PhET simulations, hiring a core team of developers in the first year.

Once the core team had assembled, after several months of developing simulations, they set down basic tenets of design elements [7]. This includes the "look and feel" of a simulation, the iterative development process (learning goals, first design, student testing and interviews, classroom use, redesigns), and the expertise required (content, programming, and education experts.) Interviews with students proved to be invaluable in interface design.

\section{2) What were the early viewpoints of the developers regarding the propagation of PhET, and how did this change over time?}

Across interviews, developers consistently stated that the intent was always to make PhET publically available, for free, on the website. However, interviews were divided on the scale of propagation from the beginning, with some surprise at PhET's broad success. Over time, PhET spread from college-focused physics simulations to other disciplines, then other grade levels, and more recently, other languages.

The PhET team is currently developing ways to reach the mobile device market by changing the coding platform from Java to HTML 5. They are also making a new website for teachers, using their body of research on how to best use the simulations with students.

"I'm hoping that [the teacher website] will be a big step forward for PhET because we have been highly effective in creating tools that teachers use and they love than they value[....]We provide so much freedom in implementation that a lot of people use them [...] We know a lot about how they can be used most effectively. But now that a lot of people are using them, it's a good time to leverage their love for the simulations to help them really use them better." PhET Team Member
3) What specific strategies did the developers use to propagate PhET?

The PhET team used (and continues to use) a variety of dissemination activities to spread the word, summarized in Figure 3.

"And he was out giving talks about PhET from the very beginning, basically telling...because he was invited to give talks all over the place, all over the world for [Bose-Einstein condensate] and he figured out how to squeeze PhET in and eventually turn those into PhET talks, because that was what he wanted to do next." -PhET Team Member

PhET benefitted from Wieman's frequent presentations, but they also actively reached out to target communities. One example is having an exhibit booth at conferences.

"..We ran exhibitor booths and we would tell people about PhET, and that really got out to a lot of people...we got to a point where we never ran into anybody who never heard of PhET, everybody had heard of PhET and was already using PhET, so we weren't getting any new people."- PhET Team Member

The PhET team also engaged in many typical activities: writing papers, giving presentations, and giving workshops both locally to high school teachers and nationally to faculty. However, while workshops are commonly thought to be important to dissemination, the team across interviews claimed that the workshops did not reach many people compared with other methods.

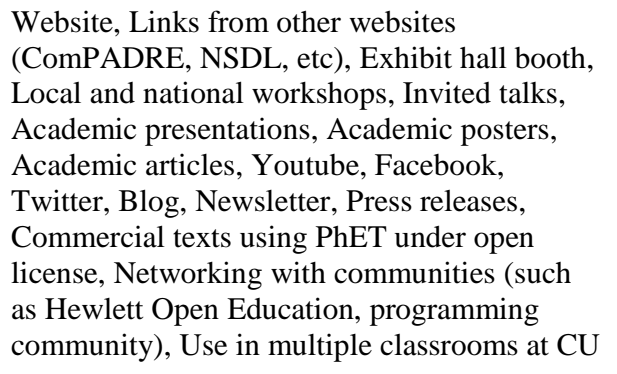

FIGURE 3. List of dissemination strategies used.

\section{4) How did funding play a role in the propagation of PhET?}

Overall, funding allowed for a large team of researchers and developers to make a credible product 
based on extensive research. In other ways, funding directly influenced new expansions into other audiences. One NSF grant was written as a joint physics-chemistry effort, which led the expansion into first chemistry and then other disciplines. Funding from King Saud University prompted the translation of PhET into Arabic [8], leading into the development of a translator utility to allow bilingual instructors around the world to easily translate simulations into other languages. Funding from and interaction with the Hewlett Foundation led to a change in licensing to Creative Commons-Attribution, meaning publishers could use PhET freely. Now, many textbooks link to the PhET simulations as examples and in online homework.

\section{DISCUSSION}

Using the existing framework and knowledge of the literature on other successful innovations, we found three key points regarding the propagation strategies of the PhET developers.

First, the PhET team had a "trial period" before setting down exactly what their innovation is. They set down what constitutes a successful simulation after this trial period. This model of moving from a "proofof-concept" phase to a larger trial phase and finally to a large-scale phase is found in medical and engineering literature [9]. We incorporated this into the new working framework in Figure 2 by splitting the "development" phase into two parts, a proof-ofconcept phase followed by a refinement period.

Second, incoming funding, often in the form of separate grants, prompted new propagation efforts. The King Saud partnership led to the translation utility which allows users around the world to translate PhET themselves, thereby growing the potential audience. We incorporated a mention in the working framework in Figure 2 that ongoing funding is ideal for successful propagation.

Third, the PhET team looks forward, continuing to make propagation efforts. PhET is currently making a new teacher website and spreading to mobile devices. In the past they used innovative methods to spread the word on PhET, such as using an exhibit booth. To incorporate this idea of continuing to innovate, we added a recursive arrow between "disseminating" and "refinement," showing that even at the wider scale phase it is ideal to continue tweaking the product.

We also note that the nature of the innovation - that PhET is flexible, free, and quick to use, dictates future directions and dissemination methods. PhET fits the original framework through its very nature of easy-tointegrate activities (thus thinking about aspects of the educational system), even though the obvious propagation efforts took place after the "refinement" period.

These key findings: having a refinement period, ongoing funding, and constant thinking ahead, led to a refined working framework for successful propagation. The framework for successful propagation will continue to evolve over the course of future studies.

\section{ACKNOWLEDGMENTS}

The authors thank the members of the PhET team who participated in this study, along with Pratibha Varma-Nelson. This paper is based upon work supported by the National Science Foundation under Grant No. 1122446.

\section{REFERENCES}

1. J. Tront, F. McMartin, and B. Muramatsu, "Improving the Dissemination of CCLI (TUES) Educational Innovations," Proceedings of the ASEE/IEEE Frontiers in Education Conference (2011).

2. E. M. Rogers, Diffusion of Innovations (fifth ed.). New York, NY: Free Press, 2003.

3. R. K. Yin, Case study research: Design and Methods, Thousand Oaks, CA: SAGE Publications, (2009).

4. C. Henderson, R. Cole, J. Froyd, and R. Khatri, "Five Claims about Effective Propagation.” (2012), white paper.

http://homepages.wmich.edu/ chenders/Publications/201 2WhitePaperFiveClaims.pdf

5. R. Khatri, C. Henderson, R. Cole, J. Froyd, "Successful Propagation of Educational Innovations: Viewpoints from Principal Investigators and Program Directors," Proceedings of the Physics Education Research Conference (2012).

6. L. Gafney and P. Varma-Nelson, Peer-Led Team Learning: Evaluation, Dissemination, and Institutionalization of a College Level Initiative. Springer Science + Business Media B.V, 2008.

7. W. Adams et al., "A Study of Educational Simulations Part I - Engagement and Learning," Journal of Interactive Learning Research, 19(3), 397-419, (2008).

8. W. Adams et al., "Making Science Simulations and Websites Easily Translatable and Available Worldwide: Challenges and Solutions," Journal of Science Education and Technology, 21(1), 1-10, (2012).

9. H. Burkhardt and A. H. Schoenfeld, "Improving Educational Research: Toward a more useful, more influential, and better-funded enterprise." Educational Researcher, 32(9), 3-14, (2003). 